\title{
空間・時間分布特性を有する地震動シミュレーション SIMULATION OF SPATIALLY AND TEMPORALLY VARIATIVE
EARTHQUAKE GROUND MOTIONS
}

\author{
星谷 勝*·石井清**・栗田博昭*** \\ By Masaru HOSHIYA, Kiyoshi ISHII and Hiroaki KURITA
}

\begin{abstract}
An input model properly representing mutually correlated earthquake ground motions is inevitably required in dynamic analysis of large scale line-like or network-like structures such as suspension bridges and buried pipelines. In this context, this paper investigated a simulation method of spatially as well as temporally variative earthquake ground motions by utilizing an autoregressive model where the properties of the actual propagating ground motions were taken into consideration in the model representation. The simulation method was justified by showing the consistency of the properties of simulated waves to the prescribed ones.

Keyroords : probability, spatial and time dependent ground motion, input model, simulation, AR model
\end{abstract}

\section{1.はじめに}

近年, 構造物の長大化に伴い, 橋梁や地中埋設パイプ ライン等の長大構造物の耐震安全性の検討が, 重要な課 題となってきている.このような長大構造物を対象に確 率論的手法を用いて応答解析を行うとき, 構造物の各支 点には，互いに相関を有した地震動が作用することを考 慮すれば, 多点入力の適切な確率過程モデルが重要とな る.

一方, 確率論的手法を用いた応答解析では, 確率過程 入力に対する応答として, 共分散応答が得られる. 星谷, 涉沢 ${ }^{1,21}$ は, 長大構造物の各支点に, 互いに相関を有す る入力が作用する場合の構造系の応答共分散を効率よく 算出する漸化理論式の誘導を行っている.この漸化理論 式において入力波形は, 多点で互いに相関を有するよう に, 時間領域の自己回帰モデル [Autoregressive Model ; AR モデル] で表わされている. この入力モデルで 与えられている多点入力波形の相互の相関, すなわち,

* 正会員 Ph.D. 武藏工業大学教授 工学部土木工学科 ( (158 世田谷区玉堤 1-28-1)

** 正会員 工博 清水建設(株)大崎研究室主任研究員 ( ( 100 千代田区内幸町 2-2-2)

*** 正会員 日本通信協力(株)(前-武蔵工業大学大学院工学 研究科修士課程)
地震動の空間・時間分布特性は, 波動の伝播に伴う各点 での時間ずれについてのみであり, 実際の観測波形にみ られるような波形そのものの変形については考虑されて いない.また，地震動の空間・時間分布特性については, アレー観測データに基づき, 各種の統計確率モデルが研 究されているが(3) 14), モデルが確定するには, 今後, 実 データの蓄積を待たなければならないのが現状である.

そこで, 本論文では, 地震動の空間・時間分布特性を 表わす統計確率モデルの既存の研究成果に基づき, 応答 共分散漸化式の多点入力として組み込むことが可能な AR モデルを用いて, 多点地震動をシミュレートするこ とを目的とする.さらに，この手法によりシミュレート されたひと組のサンプル波が, 与えた地震動の空間・時 間分布特性を満足することを, 数値計算例により示すこ ととする.

\section{2. 地霞動の空間・時間分布特性}

\section{（1）地霍動の統計確率論的表現}

地表面地震動は震源のメカニズム, 伝播経路とその媒 体, 地表面近傍地盤などの影響を強く受ける複雑な運動 である.この複雑な地表面における地震動の空間的およ び時間的な振動分布特性を表現するためには, アレー観 測で得られる多点同時観測データをひと組のサンプル実 
現値として扱う統計確率論的手法が用いられる.ライフ ライン, 吊橋, あるいは火力発電所タービン建屋などの ように空間的に広い領域を占める巨大構造物の耐震設計 においては，地震動の空間・時間分布特性を明らかにし て，多点地震入力波を作成することが必要となる.

ここで, 2 地点の位置ベクトルを $\vec{x}, \vec{x}^{\prime}$ として, 時間 $t, t^{\prime}$ におけるそれぞれの地点の地震動を $u(\vec{x}, t)$, $u\left(\vec{x}^{\prime}, t^{\prime}\right)$ とすれば, 相互相関関数は次に示す集合平均 で定義される ${ }^{3), 4}$.

$$
R\left(\vec{x}, \vec{x}^{\prime}, t, t^{\prime}\right)=E\left[u(\vec{x}, t) u\left(\vec{x}^{\prime}, t^{\prime}\right)\right]
$$

もし，表層地盤が均一 (homogeneous) であり，か つ波動伝播方向に対して異方性 (nonisotropic) の地震 動を想定するならば，上式の相互相関関数は空間座標系 においては 2 地点間の距離ベクトル $\vec{x}_{0}=\vec{x}-\vec{x}^{\prime}$ の関数 となる。ここで, 著者らは, homogeneous とは, 地震 動が空間座標系において定常である場合を考えている. 物理的には, パワースペクトル密度関数がどの地点でも 同一な地盤を仮定している．地震動が空間的に定常性を 有するかどうかに対する物理的な解釈や条件は現時点で はあまりはっきりしておらず今後の研究に負うところが 多い。しかし，工学的には，当分の間このような取扱い も許されるものと考えられる．たとえば，原子力発電所 設計用の基準地震動設定において考えられている解放基 盤という概念 ${ }^{15)}$ は，上記の仮定とほぼ一致する。また， 地震動の定常性（stationarity）を仮定するならば，時 間座標系においては，時間差の関数となる.

以上より, 2 点間の地震動の相互相関関数は

$$
R\left(\vec{x}_{0}, \tau\right)=R\left(\vec{x}, \vec{x}^{\prime}, t, t^{\prime}\right)
$$

となる.ただし, $\vec{x}_{0}=\vec{x}-\vec{x}^{\prime}, \tau=t-t^{\prime}$

式（2）をWiener-Khintchine 関係式を用いて時間 領域から振動数領域へ変換すれば，次の相互スペクトル 密度関数が得られる.

$$
S\left(\vec{x}_{0}, f\right)=\int_{-\infty}^{\infty} R\left(\vec{x}_{0}, \tau\right) e^{-i 2 \pi s \tau} d \tau \text {. }
$$

また式（2）で $\tau=0$ とおけば，次に示す空間領域にお ける自己相関関数が得られる.

$$
R\left(\vec{x}_{0}\right)=R\left(\vec{x}_{0}, 0\right)
$$

さて，地震動の空間・時間分布特性を統計確率論的に 扱った研究は多数あるが, それらの代表的な研究は, ( i ) アレー観測データに基づいて式（2）の相互相関関数 $R\left(\vec{x}_{0}, \tau\right)$ または式（3）の相互スペクトル密度関数 $S\left(\vec{x}_{0}, f\right)$ のモデル化を試みたもの ${ }^{1), 2), 4) \sim 11)}$ と（ii）同様 のデータから空間領域における式（4）の自己相関関数 $R\left(\vec{x}_{0}\right)$ のモデル化を試みたもの ${ }^{10) \sim 13)}$ に分類される. また 地震動の平面変動分布をシミュレートする目的で, 波数 スペクトル $S(k)$ を $R\left(\vec{x}_{0}\right)$ から変換して求めた研究もあ $る^{(0), 11), 14)}$.

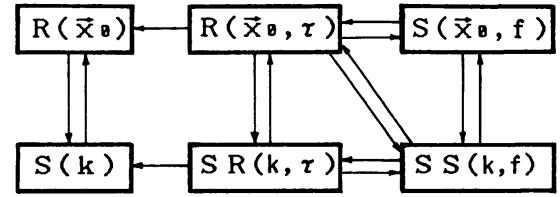

図一1 地零功の空間・時間分布特性を表わす統計確率モデルの 相互関係

以上，それぞれのモデルは図一1に示されるように， Wiener-Khintchine 関係式で結ばれるものであるから， モデル化に際し，各モデル間の整合性が満足されていな ければならない。 また，地震動を空間的な広がりの中で 動的現象としてとらえる目的からは，基本となるモデル は相互相関関数 $R\left(\vec{x}_{0}, \tau\right)$ または相互スペクトル密度関 数 $S\left(\vec{x}_{0}, f\right)$ である. なお, 図一1において, $S S(k, f)$, $S R(k, \tau)$ はそれぞれ $S\left(\vec{x}_{0}, f\right), R\left(\vec{x}_{0}, \tau\right)$ を波数領域へ 変換したものである.

\section{（2）相互スペクトル密度関数モデル}

星谷, 浩沢 ${ }^{1), 2}$ は, 表首地盤を均一とし, かつ波動の 伝播速度を一定と仮定し, 各地点で波形変形が全くない 場合の相互スペクトル密度関数モデルを次式で与えてい る.

$$
S\left(\vec{x}_{0}, f\right)=S(f) e^{-i 2 \pi f \vec{x}_{0} / c}
$$

ここで, $\vec{x}_{0}=2$ 地点間の距離ベクトル

$c=$ 地表面に沿う波動の伝播速度の大きさ（ス

$$
\text { カラー量) }
$$

$S(f)=$ 均一場の代表地点における定常地震動のパ

$$
\text { ワースペクトル密度関数 }
$$

実際には，2地点で観測された地震動波形は，2地点間 距離 $\left|\vec{x}_{0}\right|$ が大きくなるほど相関が低下し，またその傾 向は高振動数成分波ほど大となる観測結果が得られてい る ${ }^{16) ~ 18)}$.この結果を踏まえて，川上占 7) は波動伝播方向 に沿う直線上の多点定常地震動（実体波）を対象として, この相関特性を表現する相互スペクトル密度関数モデル を次式のように与えている.

$$
\begin{aligned}
& S\left(\vec{x}_{0}, f\right)=S(f) \gamma\left(\vec{x}_{0}, f\right) \\
& \gamma\left(\vec{x}_{0}, f\right)=\exp \left(-\alpha|f|\left|\vec{x}_{0}\right| / c\right) \exp \left(-i 2 \pi f \vec{x}_{0} / c\right)
\end{aligned}
$$

ここで, $c=$ =地表面に沿う波動の伝播速度の大きさ（ス カラー量).川上は実体波を考えており， $c$ は振動数によらず一定

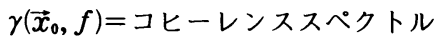

$$
\begin{aligned}
& \left|\gamma\left(\vec{x}_{0}, f\right)\right|=\exp \left(-\alpha|f|\left|\vec{x}_{0}\right| / c\right) ; \text { コヒーレンス } \\
& \alpha=\text { 波形変形定数（正値） }
\end{aligned}
$$

式（6）の特徵はコヒーレンスが伝播時間 $\left|\vec{x}_{0}\right| / c$ と 振動数 $f$ が大きくなると指数関数的に低下することを 示すことである. また， $\alpha$ は波形の変形の程度を表わす ものであり， $\alpha=0$ のときには常にコヒーレンス $\mid \gamma\left(\vec{x}_{0}\right.$, 
$f) \mid=1$ となり, 2 点間の波形は同一であり, 波形変形 はない. 星谷, 渋沢の示した式（5）はこの場合に相当 する，aが大きくなるに従い，コヒーレンスは低下し， 2 つの波形間での波形変形が進む. 川上は文献 16) -18) などを参照して，この波形変形定数 $\alpha$ の值を $0.2 \sim 0.4$ としている. 式（6）の右辺における $\exp (-i 2$ $\left.\pi f \vec{x}_{0} / c\right)$ は波動伝播による $2 つ の$ 波形間の位相ずれを 与えるものである. 川上のモデルでは波動伝播方向の直 線上での地震動を考えているが, 地震動を空間的な広が りの中で表現するためには, 式（6）を拡張する必要が あろう.

一方, Harichandran と Vanmarcke ${ }^{3), 8)}$ は地盤の均一 性, 地震動の定常性および異方性を想定して地震動の空 間・時間分布特性を検討している，すなわち，空間的な 広がりの中で, ぼの地点でのパワースペクトル密度関数 も一定であるが, 地震動の位相ずれは波動の伝播速度の 方向ベクトル $\vec{c}$ と 2 点間距離ベクトル $\vec{x}_{0}$ のなす角度に よって異なるという異方性を考慮して，相互スペクトル 密度関数を次式で提案している.

$S\left(\vec{x}_{0}, f\right)=S(f) \gamma\left(\vec{x}_{0}, f\right)$

$\gamma\left(\vec{x}_{0}, f\right)=\left|\gamma\left(\vec{x}_{0}, f\right)\right| e^{-i 2 \pi s d}$

ここで,

$$
\begin{aligned}
& \left|\gamma\left(\vec{x}_{0}, f\right)\right|=A \exp \left\{-\frac{2\left|\vec{x}_{0}\right|}{\alpha^{\prime} \theta(f)}\left(1-A+\alpha^{\prime} A\right)\right\} \\
& +(1-A) \exp \left\{-\frac{2\left|\vec{x}_{0}\right|}{\theta(f)}\left(1-A+\alpha^{\prime} A\right)\right\} \\
& \theta(f)=k\left\{1+\left(\frac{f}{f_{0}}\right)^{b}\right\}^{-\frac{1}{2}}: \text { 相関距離指標 } \\
& d=\frac{\vec{c} \cdot \vec{x}_{0}}{|\vec{c}|^{2}}: \text { 時間ずれ }
\end{aligned}
$$

$\theta(f)$ は相関距離指標 (frequency dependent correlation distance) とよび, 2 点間地震動の相関度を振動数 依存の距離尺度で示したものといえる. 式 $(7)$ のモデ ルではコヒーレンス $\left|\gamma\left(\vec{x}_{0}, f\right)\right|$ が 2 点間距離 $\left|\vec{x}_{0}\right|$ と相 関距離指標 $\theta(f)$ との比に対して指数関数的に減少して いくものであり，川上のモデル式（6）のように伝播時 間が相関の減少の要因となっていない点が異なる.なお, アレー観測データなどの解析によって, 式 $(7)$ （ 9 ) における定数 $A, \alpha^{\prime}, k, b, f_{0}$ を定めればこのモデルは 実デー夕に適合する一般的なモデルであるとしている.

また, 式 ( 7 ) では位相ずれに対して地震動伝播の異方 性を考慮している. 実際の地震動では地震波の伝播に伴 い, 各点で時間ずれ $d$ が生じる. この時間ずれ（位相 ずれに対応）は平面上で $\vec{c}$ と $\vec{x}_{0}$ とのなす角度を $\phi$ とお くと, 式 (10) より

$$
d=\frac{\vec{c} \cdot \vec{x}_{0}}{|\vec{c}|^{2}}=\frac{\left|\vec{x}_{0}\right|}{|\vec{c}|} \cos \phi
$$

となる.

つまり, 各点における地震動の時間ずれは $\vec{c}$ と $\vec{x}_{0}$ と のなす角度 $\phi$ と $|\vec{c}|,\left|\vec{x}_{0}\right|$ とによって定まる. $\phi=0$ の ときは波動伝播方向となるから川上の式と同一となる が，たとえば $\phi=90^{\circ}$ とすると $d=0$ となる。すすなわち， 地震動の伝播方向と直角な直線上の多点間では時間ずれ は生じない.このように, 波動伝播方向と距離ベクトル との位置関係によって位相ずれが影響を受けるという異 方性を考慮している. なお $|\vec{c}|$ は見掛けの伝播速度で あり, 文献 3)，8）のアレー観測で考虑している $2 \mathrm{~km}$ 程度の広がりの空間においては, 波の分散性を考える必 要はなく, 式 (10) により時間ずれは十分に表現できる としている.

相互スペクトル密度関数モデルとしては, 他に原田 ${ }^{9}$, $\mathrm{Loh}^{10), 11)}$ などの提案したものがある。また，空間での 自己相関関数モデルに関してはShinozuka と Hara$\mathrm{da}^{12), 13)}, \operatorname{Loh}^{10), 11)}$ などの研究がある。また，視点は異 なるが, 関連した研究には文献 19)〜23）など多数ある. 文献 9）ではアレー観測で得られた速度波形の解析結果 より相互スペクトル密度関数モデルを示しているが，川 上のモデル式（６）において $|f|,\left|\vec{x}_{0}\right|$ の代わりに $|f|^{\circ}$, $\left|\vec{x}_{0}\right|^{a}$ 之柔軟な形に変形したものであり, 本質的な相異 はない. 文献 10）では式（6）において，コヒーレン スの形を次に示す 4 種類の指数関数で表わしている.

$$
\left|\gamma\left(\vec{x}_{0}, f\right)\right|=\left\{\begin{array}{l}
\exp \left(-\alpha_{1}\left|\vec{x}_{0}\right|\right) \cdots \cdots \cdots \cdots \cdots \cdots(12 \cdot \mathrm{a}) \\
\exp \left\{-\alpha_{1}\left|\vec{x}_{0}\right| \cdot\right. \\
\left.\left(1+\alpha_{1}\left|\vec{x}_{0}\right|+\alpha_{1}\left|\vec{x}_{0}\right|^{2}\right)\right\} \cdots \cdots \cdots \cdots(12 \cdot \mathrm{b}) \\
\exp \left(-\alpha_{1}^{2}\left|\vec{x}_{0}\right|^{2}\right) \cdots \cdots \cdots \cdots \cdots \cdots(12 \cdot \mathrm{c}) \\
\exp \left(-\left(\alpha_{1}+\alpha_{2} 2 \pi f\right)\left|\vec{x}_{0}\right|\right) \cdots \cdots(12 \cdot \mathrm{d})
\end{array}\right.
$$

上式において, 式 $(12 \cdot a) \sim(12 \cdot c)$ は振動数に対して独 立な関数形となっている. 式 $(12 \cdot \mathrm{d})$ で $\alpha_{1}=0$ かつ $\alpha_{2}$ $=\alpha / 2 \pi c$ とおけば, 式 $(6)$ に一致する.

以上に示したように, 地震動の相互スペクトル密度関 数モデルはすべて次の基本形で与えられている.

$$
S\left(\vec{x}_{0}, f\right)=S(f) \gamma\left(\vec{x}_{0}, f\right)
$$

本研究では, 地震波動伝播による異方性を考慮してい る Haricandran と Vanmarcke のモデル式 $(7) \sim(10)$ を採用することとするが, コヒーレンスの形が比較的簡 単な Loh のモデル式 $(12 \cdot d)$ を基本モデルとすること も考えられよう.なお, 次節以降でシミュレーション法 を検討することとする.

\section{3. 多点地震動のシミュレーション}

\section{（1）定常 AR モデル}

互いに相関を有する多点地震動を確率過程理論に基ゔ 
いてシミュレートする方法には大きく分けて, 周波数領

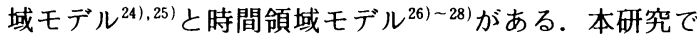
は時間領域モデルのうちで, 応答共分散漸化式の多点入 力 $^{11,2)}$ として組込みが可能な自己回帰モデル [Autoregressive Model ; AR モデル] を採用することにする. AR モデルによる方法は, 要求される地震動の相互相関 特性を満足するようにモデルの係数を決定する方法であ る. したがって地震動の空間・時間分布特性を示す相互 相関関数 $R\left(\vec{x}_{0}, \tau\right)$ が必要となる.これまでの研究は, 主に, アレー観測データから相互スペクトル密度関数 $S\left(\vec{x}_{0}, f\right)$ または, 空間での自己相関関数 $R\left(\vec{x}_{0}\right)$ のモデル 化を試みたものであり相互相関関数 $R\left(\vec{x}_{0}, \tau\right)$ について はモデル化されていない.

そこで,これまでの研究成果を踏まえて, 多点地震動 を AR モデルによりシミュレートするには，相互スペ クトル密度関数 $S\left(\vec{x}_{0}, f\right)$ をフーリエ逆変換することに より, 次式の相互相関関数 $R\left(\vec{x}_{0}, \tau\right)$ を求めることにな る.

$$
R\left(\vec{x}_{0}, \tau\right)=\int_{-\infty}^{\infty} S\left(\vec{x}_{0}, f\right) e^{i 2 \pi f \tau} d f
$$

ここで, 式 ( 7 ) および式 (13) を用いれば, 上式は, $R\left(\vec{x}_{0}, \tau\right)=2 \int_{0}^{\infty} S(f)\left|\gamma\left(\vec{x}_{0}, f\right)\right| \cos 2 \pi f(\tau-d) d f$

ここで, 式 (10) より, $d=\frac{\vec{c} \cdot \vec{x}_{0}}{|\vec{c}|^{2}}:$ 時間ずれ

である. 式（15）により, パワースペクトル密度関数 $S(f)$ さえ与えれば, 相互相関関数は数值解析的に求め ることができる.

多点地震動を平均値が 0 の定常確率ガウス過程とみな すとき, その定常 AR モデルの基本式は次式で与えら れる(1),2),26),29).

$$
u_{i}(j)=\sum_{\rho=1}^{m} \sum_{k=1}^{M} b_{i \rho}(k) u_{\rho}(j-k)+\varepsilon_{i}(j)
$$

ここで, $\quad i=1,2, \cdots, m(m:$ 地点数 $)$

$j=1,2, \cdots, N(j:$ 時刻を表わす指標で, $t$ $=(j-1) \Delta t: \Delta t$ は離散時間間隔 $)$

$M:$ AR モデルの次数

$N: 1$ 波形のシミュレーションの離散デー夕個 数

である. $b_{i p}(k)$ は振動数特性に関与する確定関数, $\varepsilon_{i}(j)$ は平均值 0 の確率過程であり, 以下の方法で求めること ができる.

このモデルでは, 相互相関関数 $R\left(\vec{x}_{0}, \tau\right)$ が与えられ ると最小二乗誤差の基準により, 初めに係数 $b_{i p}(k)$ が 定まる. 次に，係数 $b_{i p}(k)$ と相互相関関数 $R\left(\vec{x}_{0}, \tau\right)$ 之 から $\varepsilon_{t}(j)$ の共分散の値が定まる.これらの值を用いれ
ば, 多点地震動は, 式 (16) によりシミュレートされる.

まず, 最小二乗誤差の基準 $\sum_{i=1}^{m} E\left[\varepsilon_{i}^{2}(j)\right] \rightarrow$ minimum より，係数 $b_{i p}(k)$ を末知量とする次の Yule-Walker 式 が誘導される.

$$
\begin{gathered}
\sum_{p=1}^{m} \sum_{k=1}^{M} b_{n p}(k) R_{p q}(k-l)=R_{q n}(l) \\
\text { ここで, } \quad n=1,2, \cdots, m \\
q=1,2, \cdots, m \\
l=1,2, \cdots, M
\end{gathered}
$$

なお, $R_{p q}(l)$ は離散型の相互相関関数で,

$$
R_{p q}(l)=R(\overrightarrow{p q}, l \cdot \Delta t)
$$

と置き換えたものである.

式（17）はさらに次のようなマトリックスの形に表示 することができる.

$$
\left[\begin{array}{cccc}
\boldsymbol{R}_{11} & \boldsymbol{R}_{21} & \cdots & \boldsymbol{R}_{m 1} \\
\boldsymbol{R}_{12} & \boldsymbol{R}_{22} & \cdots & \boldsymbol{R}_{m 2} \\
\vdots & \vdots & & \vdots \\
\boldsymbol{R}_{1 m} & \boldsymbol{R}_{2 m} & \cdots & \boldsymbol{R}_{m m}
\end{array}\right]\left[\begin{array}{c}
\boldsymbol{B}_{n 1} \\
\boldsymbol{B}_{n 2} \\
\vdots \\
B_{n m}
\end{array}\right]=\left[\begin{array}{c}
\boldsymbol{Q}_{1 n} \\
\boldsymbol{Q}_{2 n} \\
\vdots \\
\boldsymbol{Q}_{m n}
\end{array}\right]
$$

ここで, $n=1,2, \cdots, m$

また， $\boldsymbol{R}, \boldsymbol{B}$ および $\boldsymbol{Q}$ は，それぞれ以下のようになる.

$$
\begin{aligned}
\boldsymbol{R}_{p q} & =\left[\begin{array}{cccc}
R_{p q}(0) & R_{p q}(1) & \cdots & R_{p q}(M-1) \\
R_{p q}(-1) & R_{p q}(0) & \cdots & R_{p q}(M-2) \\
\vdots & \vdots & & \vdots \\
R_{p q}(1-M) & R_{p q}(2-M) & \cdots & R_{p q}(0)
\end{array}\right] \\
\boldsymbol{B}_{n p} & =\left[b_{n p}(1), b_{n p}(2), \cdots, b_{n p}(M)\right]^{r} \cdots \cdots \cdots \cdots \cdots \cdots \\
\boldsymbol{Q}_{q n} & =\left[R_{q n}(1), R_{q n}(2), \cdots, R_{q n}(M)\right]^{r} \cdots \cdots \cdots \cdots \cdots \cdots \cdots \cdots \cdots \cdots \cdots \cdots \cdots
\end{aligned}
$$

式（19）は $\boldsymbol{B}_{n \rho}$ に関する連立代数方程式であるから, $n$ $=1$ から $m$ までの, それぞれの $n$ の値に対して解けば, すべての $b_{i p}(k)$ が求められることになる.

次に, 平均値 0 の確率過程 $\varepsilon_{i}(j)$ は, 式 $(16)$ から $E$ $\left[\varepsilon_{i}^{2}(j)\right]$ を求め, 式 $(17)$ の関係を用いて整理することに より, 次のステップで作成できることがわかる ${ }^{30}$.

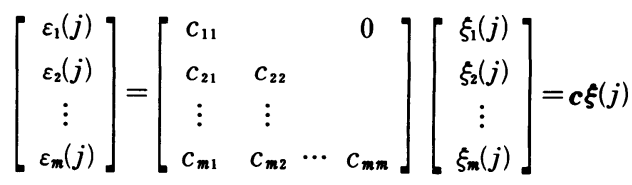

式 (23) において, $\xi$ は, $\xi_{i}(j) \neq \xi_{p}(j)(i \neq p)$ かつ $\xi_{i}(j) \neq \xi_{i}(j+l)(l \neq 0)$ を満たす平均値 0 分散 1 のガウス分 布に従う乱数である.すなわち互いに独立な White Noise 型確率過程である. そして, 式 (23) のマトリッ クス $\boldsymbol{C}$ は，共分散マトリックス $\boldsymbol{\sigma}$ を次式のように UD 分解したときの下三角マトリックスで与えられる. 


$$
\begin{aligned}
& \sigma=\left[\begin{array}{cccc}
\sigma_{11} & \multicolumn{3}{c}{\text { symmetry }} \\
\sigma_{21} & \sigma_{22} & & \\
\vdots & \vdots & & \\
\sigma_{m 1} & \sigma_{m 2} & \cdots & \sigma_{m m}
\end{array}\right]
\end{aligned}
$$

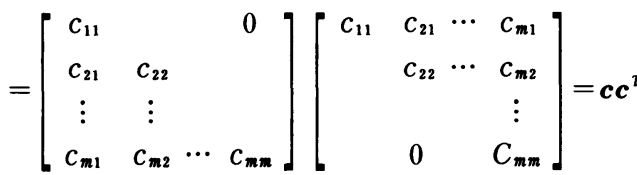

ただし，共分散マトリックス $\sigma$ の各要素は, 次式で与 えられる.

$$
\sigma_{i q}=E\left[\varepsilon_{i}(j) \varepsilon_{q}(j)\right]=R_{i q}(0)-\sum_{p=1}^{m} \sum_{k=1}^{M} b_{q p}(k) R_{p i}(k)
$$

シミュレーションは式 (19) により求まる係数 $b_{i p}(k)$ および式 $(23)$ により求まる $\varepsilon_{i}(j)$ を用いて, 式 $(16)$ により行う.

\section{（2）非定常 AR モデル}

定常 AR モデルに, 振幅の包絡曲線 $g(j)$ を乗ずるこ とにより, 振幅強度に関して非定常性を有する非定常 AR モデルを表現できる. いま, 定常確率ガウス過程を ${ }_{s} u_{i}(j)$ とおけば, 非定常確率ガウス過程 ${ }_{n} u_{i}(j)$ は, 次式 のようになる.

$$
\begin{aligned}
{ }_{n} u_{i}(j)= & g(j)_{s} u_{i}(j) \\
= & g(j) \sum_{p=1}^{m} \sum_{k=1}^{M} b_{i p}(k)_{s} u_{p}(j-k)+g(j)_{s} \varepsilon_{i}(j) \\
= & \sum_{p=1}^{m} \sum_{k=1}^{M} \frac{g(j)}{g(j-k)} b_{i p}(k) g(j-k)_{s} u_{i}(j-k) \\
& +g(j)_{s} \varepsilon_{i}(j)=\sum_{p=1}^{m} \sum_{k=1}^{M} b_{i p}(k, j)_{n} u_{\rho}(j-k)+{ }_{n} \varepsilon_{i}(j)
\end{aligned}
$$

ここで, $i=1,2, \cdots, m$

また，包絡曲線として次式を用いる11,2).

$$
g(t)=\frac{t-d}{T_{p}} \exp \left(1-\frac{t-d}{T_{p}}\right)
$$

ここで, $T_{p}+d=$ 最大振幅が生じるまでの時 間

$$
d=\frac{\vec{c} \cdot \vec{x}_{0}}{|\vec{c}|^{2}} \text { : 時間ずれ }
$$

多点地震動の場合, 平面上の各点で地震波の 伝播に伴う時間ずれが生ずるので，これを考 慮して式 (27) では, 時間ずれを $d$ で表わ している.なお，適用に際しては式 $(27)$ を 離散化して用いる.

\section{（3）数值計算例}

多点地震動を式（16）の定常 AR モデル および式（26）の非定常 AR モデルを用い
てシミュレートする.定常の場合については, シミュレー トされたひと組のサンプル波形の相互相関関数を計算 し, 規定した相互相関関数の特性を満足しているかどう かを検討した。

シミュレーションに用いる地震動の空間・時間分布特 性は, Harichandran とVanmarckeにより提案された相 互スペクトル密度関数モデル, 式 $(7)$ (10) を用いる. $\mathrm{AR}$ モデルでの地震動のシミュレーションに直接必要な 相互相関関数 $R\left(\vec{x}_{0}, \tau\right)$ は, 式（15）を用いて求めた. また, 均一な確率場の代表地点における加速度波形のパ ワースペクトル密度関数は, 後藤・亀田により提案され た次式を用いる ${ }^{31}$.

$$
\begin{aligned}
{ }_{A} S(f) & =(2 \pi f)^{2} S(f)=(2 \pi f)^{4} S(f) \\
& =\frac{64}{6 \pi f_{g}^{5}} f^{4} \exp \left(-\frac{4|f|}{f_{g}}\right) \cdots
\end{aligned}
$$

\begin{tabular}{|c|c|c|c|}
\hline \multicolumn{2}{|c|}{$\begin{array}{l}\text { ・バワースペクトル密度関数 } \\
\text { :(30) 式において }\end{array}$} & \multicolumn{2}{|c|}{$\begin{array}{l}\text { - AR ₹テテル : (16) 式と (26) 式 } \\
\text { において }\end{array}$} \\
\hline$f_{8}$ & 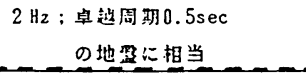 & $\mathrm{m}$ & 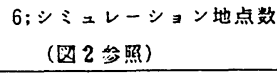 \\
\hline \multirow{3}{*}{\multicolumn{2}{|c|}{$\begin{array}{l}\text { コヒーレンススベクトル } \\
\text { :(7) -(10) 式において }\end{array}$}} & \multirow[t]{2}{*}{$M$} & 40 ；变位被のAＲ次数 \\
\hline & & & 80 ; 加遇度波のA R 欢数 \\
\hline & & \multicolumn{2}{|c|}{ ・シミュレーション波において } \\
\hline A & 0.736 & \multirow[t]{4}{*}{$\Delta t$} & \multirow{2}{*}{$\begin{array}{l}0.1 \mathrm{sec} \text {; 变位披の坫合 } \\
\text { (Nyquist振動数：5Hz) }\end{array}$} \\
\hline$\alpha^{\prime}$ & 0.147 & & \\
\hline $\mathbf{k}$ & $5210 \mathrm{~m}$; 解的な相闺距新 & & \multirow{2}{*}{ 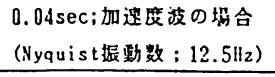 } \\
\hline$f_{0}$ & $1.09 ;$ corner frequency & & \\
\hline b & 2.78 & \multirow[t]{2}{*}{$T p$} & \multirow{2}{*}{ 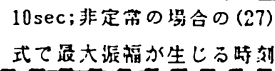 } \\
\hline $\mid \overrightarrow{c \mid}$ & $2000 \mathrm{~m} / \mathrm{sec}$ ：波助の伝揟遇度 & & \\
\hline
\end{tabular}

ここで, $f_{g}=$ 地盤の卓越振動数

${ }_{v} S(f)=$ 速度波のパワースペクトル密度関数 ${ }_{D} S(f)=$ 変位波のパワースペクトル密度関数

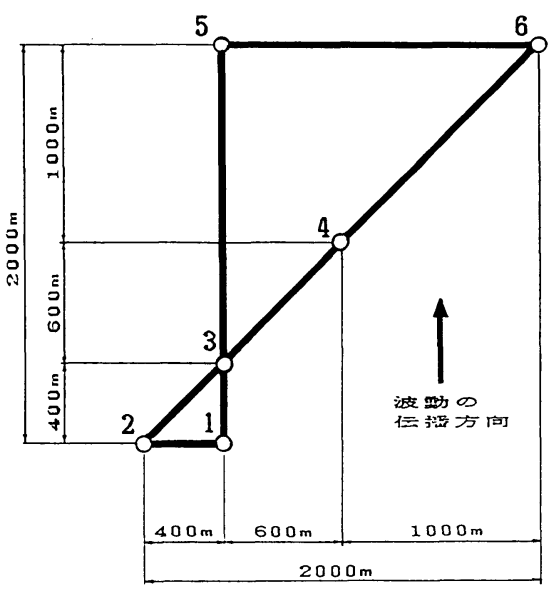

図一2 地助のシミュレーション地点の平面分布と波動の伝播 方向 


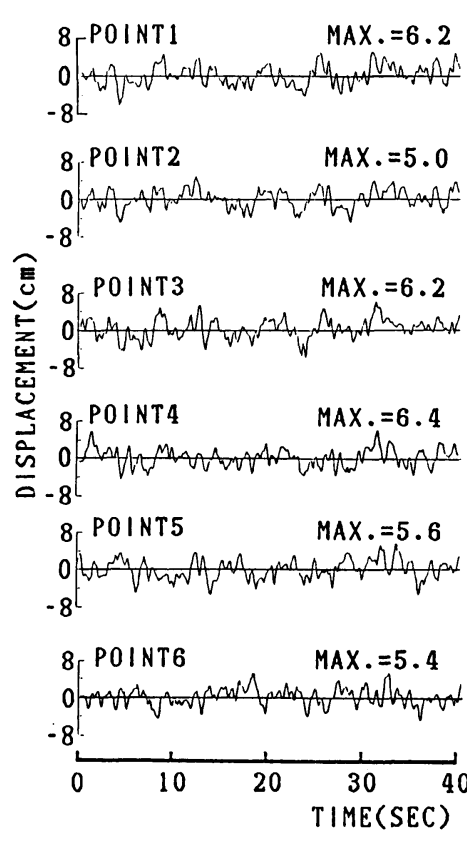

図一3 定常変位波のサンプル
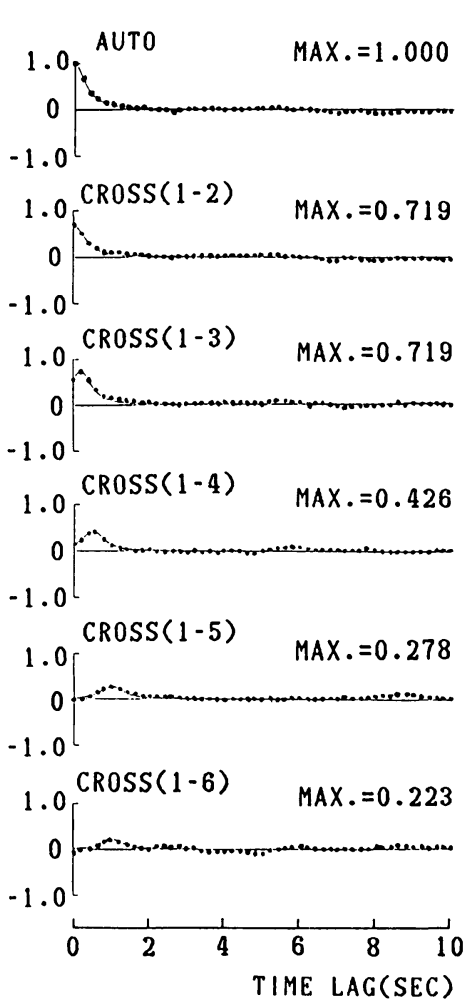
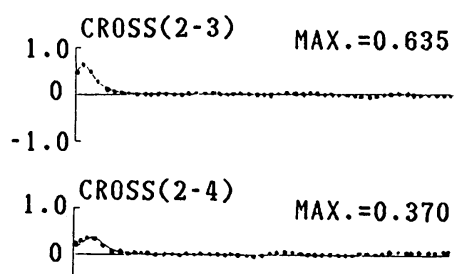

$-1.0$

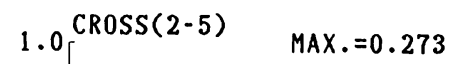

0
1.0

$1.0^{\operatorname{CrOSS}(2-6)} \operatorname{MAX} .=0.204$
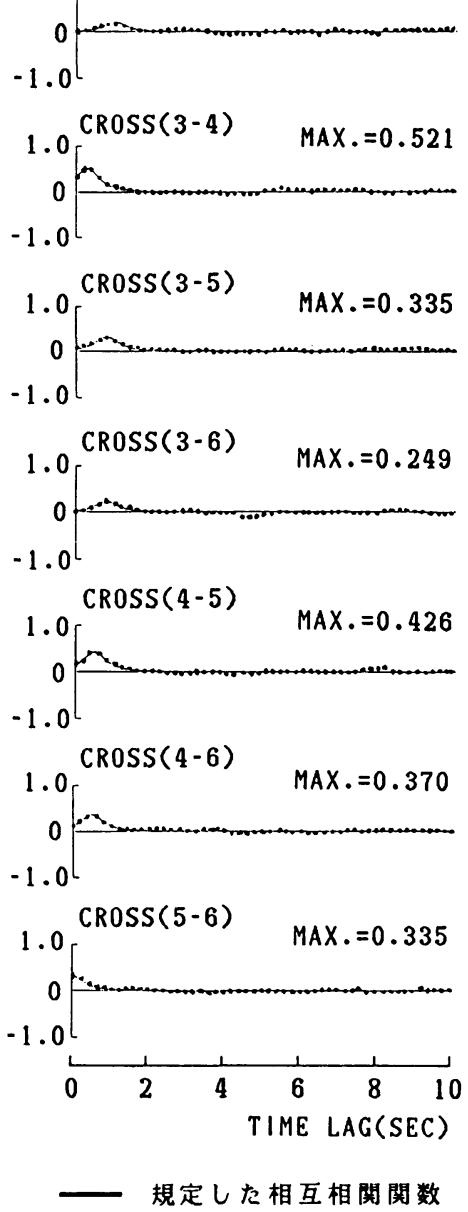

サンプル波から求めた 相互相関関数

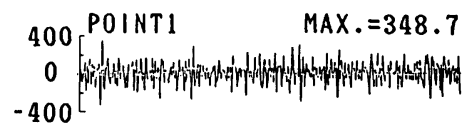
400 POINT2

$\operatorname{MAX} .=373.7$

$-400$

紊 400 POINT3 MAX. $=393.4$

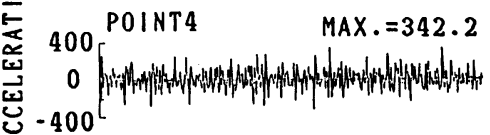
400 POINT5 MAX. $=333.1$

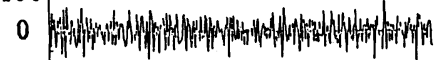
$-400$

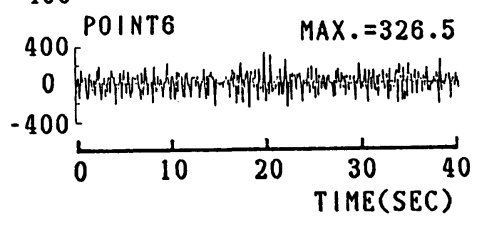

图一5 定常加速度波のサンプル
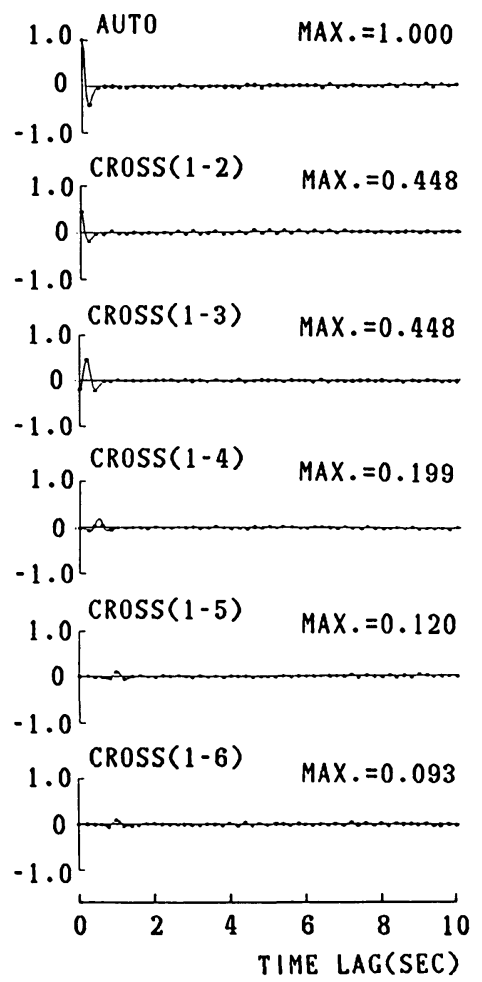

図一4 定常変位波の相互相関関数 

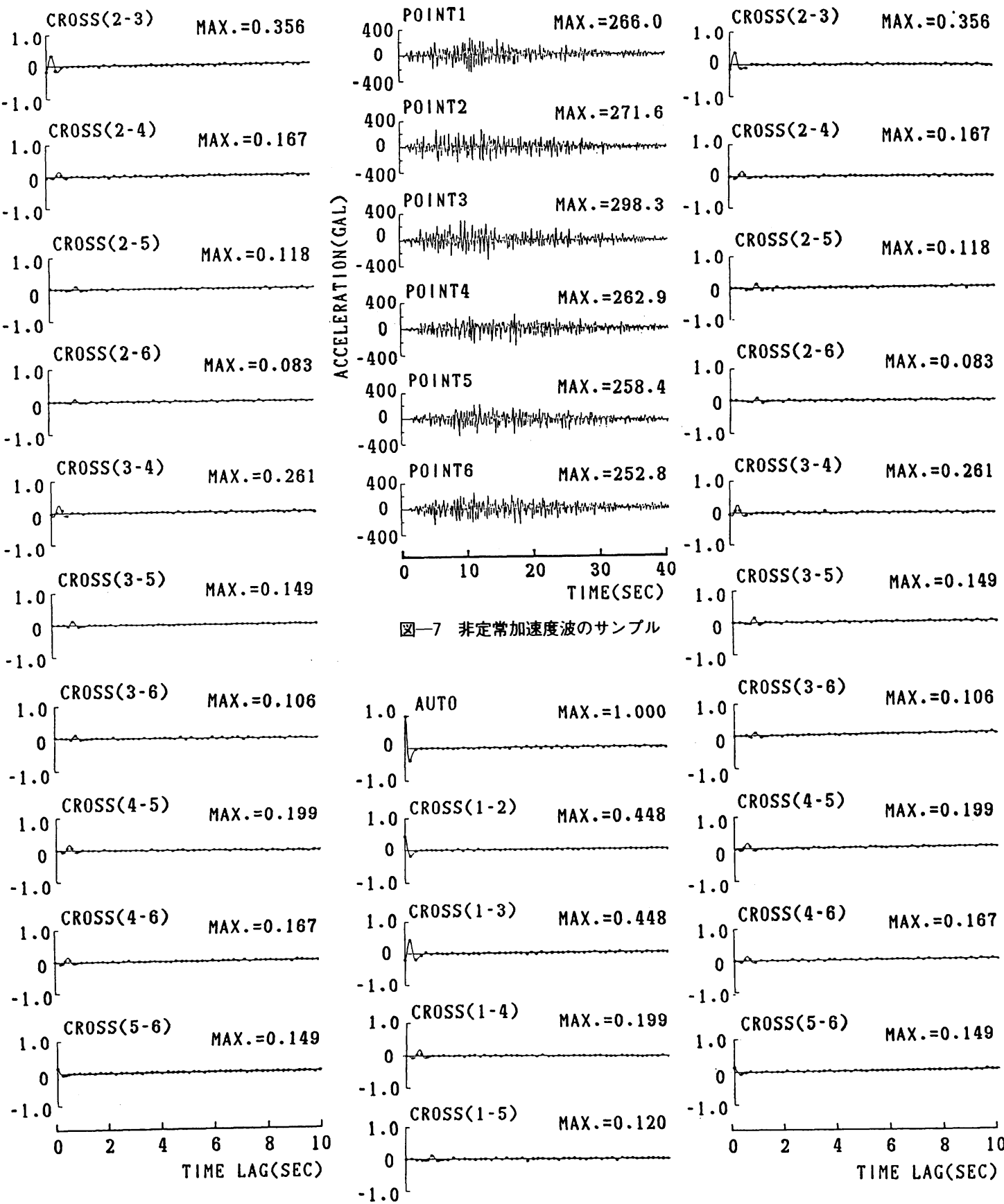

——規定した相互相関関数

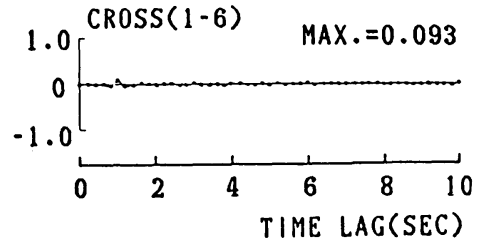

規定した相互相関関数 サンプル波から求めた 相互相関関数

図一 6 定常加速度波の相互相関関数

相互相関閲数 
シミュレーションに用いた入力諸元を表一1に示す.

この計算例では図一2に示すように, 空間 6 地点にお ける地震動が，地点 1 から地点 3,5 方向へ向かう波動 伝播に伴って，ぼのように再現するかを検討することに した.

図一3には，シミュレートされた，ひと組の定常変位 波のサンプルを示す.このようなサンプル波群を 7 組作 り，それらの相互相関関数 7 組の集合平均を求めた. 図 -4にはそれをプロット值で示す．なお，同図には実線 で規定した相互相関関数を示してあるが両者はほぼ一致 しシミュレーション結果は満足のいくものであることが わかる.ここでは，規定する相互相関関数に $R_{p q}(\tau)=$ $R_{q p}(-\tau)$ なる性質があるため $R_{p q}(\tau)(p<q)$ の結果のみ を示す．また，相関の程度をわかりやすくするために， 相互相関関数の値を $R_{11}(0)$ で正規化してある.

それぞれの相互相関関数の最大值は, 対応する 2 点間 距離 $\left|\vec{x}_{0}\right|$ が大きい 2 点間ほど小さな值となっており, ここで示した例では, 2 点間距離 $\left|\vec{x}_{0}\right|$ の最も大きい $R_{26}(\tau)$ の最大值が他のどの相互相関関数の最大値よりも 小さな值を示している．また，それぞれの相互相関関数 が最大值を示す $\tau$ は, 式 $(10)$ で示される時間ずれ $d$ と等しいときである。

まず 2 点間距離 $\left|\vec{x}_{0}\right|$ は等しいが, 時間ずれ $d$ が異な る 2 点間の相互相関を考え，図一 4 に示す相互相関関数 $R_{12}(\tau)$ と $R_{13}(\tau)$ とを比較する. 図一2より $\left|\vec{x}_{2}-\vec{x}_{1}\right|=$ $\left|\vec{x}_{3}-\vec{x}_{1}\right|$ であるから相互相関関数 $R_{12}(\tau)$ と $R_{13}(\tau)$ の最 大値は一致している. ところが, 地点 1 と地点 3 とは, 波動の伝播方向 $\vec{c}$ に沿う 2 点間であり, 式 (10) で示 される時間ずれ（この場合は $0.2 \mathrm{~s}$ ) が $R_{13}(\tau)$ の図の実 線の時間遅れに対応しているのに対し, 地点 1 と地点 2 とでは $\vec{x}_{2}-\vec{x}_{1}$ と波動の伝播方向 $\vec{c}$ とが $90^{\circ}$ をなすため に, $R_{12}(\tau)$ の図で時間ずれがみられない。これらのこと は, 相互相関関数 $R_{35}(\tau)$ と $R_{56}(\tau)$ とを比較しても同樣 である。

次に, 2 点間距離 $\left|\vec{x}_{0}\right|$ は異なるが, 時間ずれ $d$ が等 しい 2 点間の相互相関を考える. 図一 4 の $R_{15}(\tau), R_{16}(\tau)$, $R_{25}(\tau)$ および $R_{26}(\tau)$ はいずれも相互相関関数が最大值を 示す $\tau$ が等しい. しかし，それぞれの 2 点間距離 $\left|\vec{x}_{0}\right|$ は異なるため，それぞれの相互相関関数の最大値は異な る值となっている.

また, 図一3の定常変位波のサンプルからは, 図一4 の相互相関関数の最大値が小さい 2 点間ほど波形変形が 大きいこと，および各点の地震動の時間差は式 (10) で 示される時間ずれに一致することがわかる.

定常加速度波については図一5にシミュレートされた ひと組のサンプルを示す．また，このようなサンプル波 群を 18 組作り, それらの相互相関関数 18 組の集合平均
をプロット值で図一6に示し，それらが規定した相互相 関関数（実線）を満足することを示している．图一3の 定常変位波と比べると，図一5の定常加速度波において は，波動伝播に伴う時間ずれや波形変形の程度が全く不 明である. しかし，図一5のシミュレーション波が，規 定された相互相関関数を満足することは図一 6 より明確 である.

さらに, 振幅強度に関して非定常な非定常加速度波の ひと組のサンプルを図一7に示す。なお，図一8では， 参考までにこれらを定常波とみなして，相互相関関数を 求め, 同様に作成したサンプル 18 組から相互相関関数 18 組の集合平均をとり（プロット值）定常部分の波形 で規定された相互相関関数（実線）と比較してみた。図 -8 から，振幅強度に関する非定常波は，集合平均をと れば，定常波の相互相関関数を満足することがわかる.

\section{4.おわりに}

本論文は，地震動の空間・時間分布特性を表わす統計 確率モデルの既存の研究成果の相互の関係を明らかにし て,これに基づき, 互いに相関を有する多点地震動を, AR モデルによりシミュレートする手法を開発したもの である.

またこの手法によりシミュレートされた，ひと組の サンプル波が，あらかじめ規定された地震動の空間・時 間分布特性を満足することを数值計算により確認した.

なお, 計算は, 東京大学大型計算機センターのM 682 H計算システムを利用した。

\section{参考 文 献}

1) Masaru Hoshiya and Shigehiko Shibusawa : Response Covariance to Multiple Excitations, Journal of Engineering Mechanics Division, ASCE, Vol.112, No.4, pp. 412 421, 1986. 4 .

2）星谷 勝・㗪沢重彦：多地点入力による構造系の応答共 分散渐化式の誘導亡応用, 土木学会論文集, 第 362 号／ I-4, 1985 年 10 月.

3) Vanmarcke, E.H. : Random Fields: Analysis and Synthesis, MIT Press, Cambridge, MA, 1983.

4) Harichandran, R.S. : Space-Time Variation of Earthquake Ground Motion, thesis presented to the Massachusetts Institute of Technology, at Cambridge, MA, in 1985, in partial fulfillment of the requirements for the degree of Doctor of Philosophy.

5）川上英二・佐藤靖彦：地盤の相対変位・平均ひずみの推 定結果に及ぼす地震波形の変形の影響, 土木学会第 17 回 地震工学研究発表会講演概要, pp. 73 76, 1983 年 7 月.

6）川上英二・佐藤靖彦：地盤の相対変位・ひずみの推定結 果に及ぼす地震波形の変形の影響, 土木学会論文報告集, 第 337 号, pp. 37 46, 1983 年 9 月.

7）川上英二・佐藤靖彦：コヒーレンスの性質および算定方 
法に関する一考察, 構造工学論文集, Vol. 32 A, pp. 749 $\sim 762,1986$ 年 3 月.

8) Ronald S. Harichandran and Erik H. Vanmarcke: Stochastic Variation of Earthquake Ground Motion in Space and Time, Journal of Engineering Mechanics Division, Vol.112, No.2, pp. 154 174, 1986.2.

9）原田隆典・高本智博・堤一・赤木正見：アレ一観測 記録による地震動の空間的変動特性の解析について, 土 木学会第 40 回年次学術講演会講演概要, 第 1 部門, pp. 809 810, 1985 年.

10) Chin Hsiung Loh: Analysis of the Spatial Variation of Seismic Waves and Ground Movements from SMART1 Array Data, Earthquake Engineering and Structural Dynamics, Vol. 13, pp. 561 581, 1985.

11) Loh, C. H. and Leu, C. Y. : Analysis of Spatial Characteristics of Seismic Ground Motions SMART-1 Array Data, Proceedings of the Trilateral Seminar-Workshop on Lifeline Earthquake Engineering, Taipei, Taiwan, pp. 107 121, November, 1985.

12) Shinozuka, M. and Harada, T. : Spatial Variabilities of Seismic Ground Motions and their Design Implications for Buried Lifeline Structures, Proceedings of the Trilateral Seminar-Workshop on Lifeline Earthquake Engineering, Taipei, Taiwan, pp. 249 263, November, 1985.

13) Harada, T. : Probabilistic Modeling of Spatial Variation of Strong Earthquake Ground Displacements, 8th WCEE, San Francisco, Vol. II, pp. 605 612, 1984.

14）原田隆典 - Shinozuka, M. : 地震動の工学的平面分布モ デルにおける確率過程理論の応用, 土木学会第 16 回地震 工学研究発表会講演概要, pp. 129 132, 1981 年.

15）大崎順彦：原子力発電所設計用の基準地震動評価に関す るガイドライン, ORI 研究報告, 1984 年 12 月.

16）石井 清：確率論手法による地震波の入力損失の検討, 清水建設研究所報, 34 号, pp. 43 53, 1981 年.

17）石井 清：確率論手法による地震波の入力損失の効果の 検討, 土木学会第 16 回地震工学研究発表会講演概要, pp. $317 \sim 320,1981$ 年.

18) Masaru Hoshiya and Kiyoshi Ishii : Evaluation of Kinematic Interaction of Soil-Foundation Systems by a Stochastic Model, Soil Dynamics and Earthquake Engineering, ( 3 ), pp. 128 134, 1983.2.

19）山田善一・野田 茂・香川明生：SMART 1 アレー観測 記䩮を用いた各種の波動論的考察, 構造工学論文集, Vol. $32 \mathrm{~A}$, pp. $763 \sim 776,1986$ 年 3 月.

20) Oliveira, C. S. and Penzien, J. : Spatial Variation of Seismic Ground Motions Based on SMART 1 Array
Data, Proceedings of the Trilateral Seminar-Workshop on Lifeline Earthquake Engineering, Taipei, Taiwan, pp. 59 75, November, 1985.

21) Tan, R. Y. and Lee, M. J. : Modeling of Ground Motions Based on SMART 1 Array Data, Proceedings of the Trilateral Seminar-Workshop on Lifeline Earthquake Engineering, Taipei, Taiwan, pp. 93 105, November, 1985.

22) Zerva, A., Ang, A.H-S. and Wen, Y. K. : Seismic Ground Motion Spectra for Lifeline Analysis and Design, Proceedings of the Trilateral Seminar-Workshop on Lifeline Earthquake Engineering, Taipei, Taiwan, pp. 233 248, November, 1985.

23) Norman A. Abrahamson and Bruce A. Bolt : The Spatial Variation of the Phasing of Seismic Strong Ground Motion, Bulletin of the Seismological Society of America, Vol. 75, No. 5, pp. 1247 1264, October, 1985.

24) Shinozuka, M. : Simulation of Multivariate and Multidimensional Random Processes, The Journal of the Accoustical Soc. of America, Vol.49, No.1, pp.357 368, Jan., 1971.

25）星谷 勝：確率論手法による振動解析, 鹿島出版会, 1974 年.

26) Masaru Hoshiya and Toshiaki Chiba: Simulation Methods of Multi-Dimensional Nonstationary Stochastic Processes by Time Domain Models, Proc. of JSCE, No. 296, pp. 121 130, April, 1980.

27) Elias Samaras, Masanobu Shinozuka and Akira Tsurui : ARMA Representation of Random Processes, Journal of Engineering Mechanics Division, ASCE, Vol.111, No. 3, pp. 449 461, 1983. 3.

28) Ahmet S. Cakmak, Russell 1. Sherif and Glenn Ellis: Modeling Earthquake Ground Motions in California using Parametric Time Series Methods, Soil Dynamics and Earthquake Engineering, Vol.4, No. 3, pp. 74 81, 1985.

29) Masaru Hoshiya, Kiyoshi Ishii and Shigeru Nagata: Recursive Covariance of Structural Responses, Journal of Engineering Mechanics Division, ASCE, Vol.110, No. 12, pp. 1743 1755, December, 1984.

30）赤池弘次・中川東一郎：ダイナミックシステムの統計的 解析と制御, サイエンス社, 1972 年.

31) Hisao Goto and Hiroyuki Kameda: Statistical Inference of the Future Earthquake Ground Motion, Proc. 4WCEE, Chile, Vol.1, A-1, pp. 39 54, 1969.

(1986.11.4 • 受付) 